DOI No: http://dx.doi.org/10.29228/Joh.49233

Authenticity process is conducted by

Makale Türü: Araştırma makalesi

Geliş Tarihi: 05-02-2021

Kabul Tarihi: 21-03-2021

On-line Yayın: 30-04-2021

Article Type: Research article Submitted: 05-02-2021

Accepted: 21-03-2021

Published Online: 30-04-2021

Atıf Bilgisi / Reference Information

Çelebi, E. \& Uncu, F. (2021). Nursing Students' Attitudes towards the Elderly People and Affecting Factors. Journal of History School, 51, 1296-1308.

\title{
NURSING STUDENTS' ATTITUDES TOWARDS THE ELDERLY AND AFFECTING FACTORS ${ }^{1}$ \\ Evrim ÇELEBİ ${ }^{2} \&$ Fatoş UNCU ${ }^{3}$
}

\begin{abstract}
This descriptive cross-sectional study was conducted to determine nursing students' attitudes towards the elderly and affecting factors between February 2019 and April 2019. The study population consisted of 563 nursing students studying at the health sciences faculty of a university. In the study, no sampling method was implemented and 454 students who were contacted at the time the data were collected were included in the study. The data were collected by the researchers in classrooms by administrating the Personal Information Form and Kogan's Attitudes toward Older People scale. While the positive attitude score of the participating students towards the elderly was $65.63 \pm 10.45$, their negative attitude score was $64.01 \pm 12.05$, and total attitude score was $129.64 \pm$ 16.47. The scores obtained by the students who followed the news about the elderly and wanted to work in institutions where older adults are served after graduation were significantly higher $(\mathrm{p}<0.001)$. Of the variables, age, sex and year at school did not affect the participating students' attitudes towards the elderly ( $p>0.001)$.
\end{abstract}

Keywords: Attitude towards Older Adults, Nursing Students, Affecting Factors

\footnotetext{
${ }^{1}$ Article writing author influence rate: First author 50\%, second author 50\%. Etical approbation: Firat University 13.12.2018/14/10

${ }^{2}$ Assist. Prof., Furat University Faculty of Health Sciences, Department of Midwifery, ecelebi@firat edu.tr, Orcid: 0000-0001-5641-5465

${ }^{3}$ Assist. Prof., Frrat University Faculty of Health Sciences, Department of Nursing, funcu@ firat.edu.tr, Orcid: 0000-0001-8077-4652
} 
Nursing Students' Attitudes towards the Elderly and Affecting Factors

\section{Hemşirelik Öğrencilerinin Yaşlılara Yönelik Tutumları ve Etkileyen Faktörler}

\section{$\ddot{O}_{z}$}

$\mathrm{Bu}$ çalışma hemşirelik öğrencilerinin yaşlılara karşı tutumları ve etkileyen faktörleri belirlemek amacıyla, Şubat-Nisan 2019 tarihleri arasında, tanımlayıcı ve kesitsel olarak yapılmıştır. Çalışmanın evrenini, bir üniversitenin sağlık bilimleri fakültesinde öğrenim gören toplam 563 hemşirelik öğrencisi oluşturmuştur. Çalışmada örneklem seçme yoluna gidilmemiş, verilerin toplandığı tarihlerde ulaşılan 454 öğrenci araştırma kapsamına alınmıştır. Veriler kişisel bilgi formu ve "Kogan Yaşlılara Yönelik Tutum Ölçeğii" kullanılarak araştırmacılar tarafından sınıf ortamında toplanmıştır. Öğrencilerin yaşlılara yönelik pozitif tutum puanı $65.63 \pm 10.45$, negatif tutum puanı $64.01 \pm 12.05$ ve toplam tutum puanı $129.64 \pm 16.47$ olarak bulunmuştur. Yaşlılarla ilgili haberleri takip eden ve mezuniyet sonrası yaşlılara hizmet veren kurumlarda çalışmak isteyen öğrencilerin puanları anlamlı olarak yüksek bulunmuştur $(\mathrm{p}<0.001)$. Yaş, cinsiyet ve sınıf düzeylerinin öğrencilerin yaşlılara yönelik tutum puanlarnı etkilemediği saptanmıştır ( $\mathrm{p}>0.001)$.

Anahtar Kelimeler: Yaşlılara Yönelik Tutum, Hemşirelik Öğrencileri, Etkili Fakörler

\section{INTRODUCTION}

The population aging has become a significant demographic factor in the 21 st century (Beard et al., 2016). Age structure of the global population has undergone unprecedented and continuous changes because of an increase in longevity and a decrease in fertility. The number of people aged 65 and older was 727 million in 2020 . The global elderly population is expected to more than double by 2050 and is expected to be $>1.5$ billion. The elderly population is expected to increase worldwide between 2020 and 2050; the population comprising individuals aged 65 and older is expected to increase from $9.3 \%$ in 2020 to $16 \%$ in 2050 (UN, 2020). In Turkey, adults aged 65 and older comprised the $9.1 \%$ of the total population in 2019. According to population projections, the proportion of elderly population is expected to increase to $10.2 \%$ in $2023,12.9 \%$ in 2030, and $16.3 \%$ in 2040 (TÜIK, 2019). Although the global population is aging rapidly, to date, sufficient evidence showing a direct relationship between longevity and a prolonged period of good health is not available (Beard et al., 2016). An increase in the number of elderly people has led to an increase in disorders, which in turn leads to increased spending of the majority of funds allocated to healthcare. In addition to physical and social changes associated with aging, the debilitating effects of acute and chronic disorders in the elderly population is why the healthcare services are mostly used by this population (Che et al., 2018). Healthcare institutions and healthcare professionals usually define elderly people as the ones who occupy beds, require hospitalization, and who 
cannot be treated within the healthcare system; therefore they are evaluated as a failure within the healthcare system (Duru Aşiret et al., 2015).

Due to an increase in the differences between generations in terms of the traditional culture and values, the role of the elderly people within the family diminishes and they lose their respectability; thus, age does not remain an important factor, and patient care at home has become an increasingly growing problem because of these differences. Because of factors such as changes during old age, chronic disorders, incontinence, eating disorders, dementia, incorrect use of medication, and geriatric symptoms, the elderly people have a greater need to avail the healthcare services (Erden et al., 2012). Therefore, the number of expert healthcare professionals who can provide care to the elderly within the scope of health and social services needs to be increased (Özütürker, 2019). Sociodemographic structure of the society, various beliefs attitudes and behaviors, and perception of the society toward elderly people reflects on the services provided to this population and is responsible for the various problems (Yllmaz \& Özkan, 2010). Behaviors and attitudes of the healthcare professionals regarding elderly people are as important as those of the society (Şahin \& Erdem, 2017). In addition, negative bias, values, beliefs, and attitudes of healthcare professionals toward elderly people affect the quality of the care provided to them. The nursing staff providing care to the aging population plays a critical role in increasing the quality of the healthcare services provided to elderly people. The perceptions, perspectives, and prejudices of nurses regarding old age directly or indirectly affect the studies regarding the health of elderly people (Demirtaş et al., 2019). Moreover, owing to the changes associated with aging, it becomes difficult for the nurses to provide care to the elderly people, and the increase in workload affects their desire to work with this population (Adibelli et al., 2013). The nursing students in Turkey are health issues related to the elderly, are learning in public health lessons. The nursing students today will be the nurses to directly provide care to the aging population tomorrow (Hsu et al., 2019). Therefore, determining the knowledge and attitudes of the nursing students regarding the elderly population has become extremely significant

\section{MATERIALS AND METHODS}

This was a cross-sectional and descriptive study. The study population included 563 students studying in the nursing department of the faculty of health sciences in the Firat University during the spring semester from 2018-2019. The entire population was included in the study without sampling. Researchers collected data at the end of the class identified in the program of the department between 
Nursing Students' Attitudes towards the Elderly and Affecting Factors

February and April 2018. Students were informed regarding the aim of the study before administering the surveys, and only those students who voluntarily participated in the study were given surveys. Students who did not want to complete the survey did not participate in the class, and those who did not answer all the questions were not included in the study. Surveys were collected at the end of the class and 454 students provided their responses to the questions in the survey. The rate of comprehensiveness of the study was $80.63 \%$. Study data were collected using a personal information form and Kogan's Attitudes Toward Old People Scale (KATOPS).

\section{Personal Information Form}

The personal information form was prepared after a literature review and included questions regarding the age, sex, and marital status of the students, how often they meet their old relatives, their habits of reading books and watching the news regarding old age, and their desire to work at an institution providing service to elderly people after graduation (Adıbelli et al., 2013; Alkaya \& Okuyan, 2017; Birimoğlu et al., 2020)

\section{Kogan's Attitudes Toward old People Scale (KATOPS)}

This scale was developed by Kogan (1961) to measure the attitudes of people toward old people, and the Turkish adaptation of this scale was performed by Duyan and Gelbal (2013). This scale includes 34 items and two subscales that measure the positive and negative attitudes toward old people. The first 17 items of the scale are a part of the negative attitude subscale and the remaining items (18 to 34) are a part of the positive attitude subscale. This 6-point Likert-type scale included responses as follows "strongly disagree," "disagree," "somewhat disagree," "somewhat agree," "agree," and "strongly agree". The scores on each subscale ranged from 17 to 119 and those on the entire scale ranged from 34 to 238. High scores on the positive subscale and low scores on the negative subscale indicate positive attitudes toward old people (Duyan \& Gelbal, 2013).

\section{Ethical Considerations}

Approval for the study was obtained from the university where the study was conducted before commencing the study. In addition, approval was obtained from the Social and Human Sciences Researches Ethics Committee of Firat University $(13.12 .2018 / 14 / 10)$.

\section{Data Evaluation}

Research questions are as follows:

1. What are nursing students' attitudes towards the elderly like? 
2. Do nursing students' attitudes towards the elderly vary according to their demographic characteristics?

Variables were summarized as number, percentage, and average. Data were analyzed using a t-test in the independent groups and analysis of variance (Anova). All data were analyzed using the IBM SPSS statistical software program and the significance level was statistically set at $\mathrm{p}<0.05$.

\section{RESULTS}

The mean age of the participants was $20.33 \pm 1.85$ years $($ Min. $=17$, Max.=29). Of the students, $69.8 \%$ were female, $97.8 \%$ were single, $29.3 \%$ were first year students, $31.1 \%$ were second year students, $20.3 \%$ were third year students and $19.4 \%$ were fourth year students; $32.6 \%$ of the students stated that they visited their older relatives few times a month; $92.4 \%$ did not read any book regarding old age; $54.4 \%$ did not follow news about the older population; and $50.7 \%$ stated that they were indecisive about working at an institution providing service to the elderly people (Table 1).

Table 1

Baseline Characteristics of the Nursing Students $(\mathrm{N}=454)$

\begin{tabular}{llcc}
\hline & Variables & $\mathrm{N}$ & $\%$ \\
\hline Age (years) & $17-19$ years & 166 & 36.6 \\
& 20-22 years & 252 & 55.5 \\
& 23 and above & 36 & 7.9 \\
Gender & Female & 317 & 69.8 \\
& Male & 137 & 30.2 \\
Marital Status & Single & 444 & 97.8 \\
& Married & 10 & 2.2 \\
School Year & 1st class & 133 & 29.3 \\
& 2nd class & 141 & 31.1 \\
& 3rd class & 92 & 20.3 \\
Frequency of seeing the elderly people & 4th class & 88 & 19.4 \\
in your family* & Every day & 70 & 15.4 \\
& Few times a week & 106 & 23.3 \\
Reading books regarding old age & Few times a month & 148 & 32.6 \\
& Few times a year & 104 & 22.9 \\
Following news regarding elderly & Yes & 35 & 7.7 \\
people & No & 419 & 92.3 \\
Being willing to work in an institution & Yes & 207 & 45.6 \\
providing care to the elderly & No & 247 & 54.4 \\
& Yes & 159 & 35.0 \\
& No & 65 & 14.3 \\
& Neither agree nor disagree & 230 & 50.7 \\
\hline
\end{tabular}


Nursing Students' Attitudes towards the Elderly and Affecting Factors

The scores of students on the KATOPS are shown in Table 2. The mean scores on the Positive and Negative Attitude Subscales were $65.63 \pm 10.45$ and $64.01 \pm 12.05$, respectively, and the mean total score was $129.64 \pm 16.47$.

Table 2

Distribution of the Students' Scores of KATOPS

\begin{tabular}{lccc}
\hline Subscales & $\begin{array}{c}\text { Score average } \\
\mathbf{X} \pm \text { SS }\end{array}$ & Min-Max. & $\begin{array}{c}\text { Score range } \\
\text { to be taken }\end{array}$ \\
\hline Total score & $129.64 \pm 16.47$ & $34-183$ & $34-238$ \\
Positive Attitude Score & $65.63 \pm 10.45$ & $17-102$ & $17-119$ \\
Negative Attitude Score & $64.01 \pm 12.05$ & $17-95$ & $17-119$ \\
\hline
\end{tabular}

The scores of students on the attitude scale toward old people based on their baseline characteristics are shown in Table 3. Mean scale scores of the students following the news regarding the elderly population $(132.90 \pm 15.72)$ were significantly higher than those not following such news $(126.91 \pm 16.62$, p $<0.001$ ). Students willing to work at an institution providing service to elderly people after graduation had statistically higher scores than those who were unwilling and indecisive about working at such an institution $(\mathrm{p}<0.001)$. The mean scores of students based on variables of age, gender, marital status, year, frequency of meeting the elderly relatives within the family, and reading books about old age showed a similar distribution (Table 3). 
Evrim ÇELEBİ \& Fatoş UNCU

Table 3

Comparison of the KATOPS Scores Based on their Baseline Characteristics

\begin{tabular}{|c|c|c|c|c|}
\hline & & $\mathbf{N}$ & $\mathbf{X} \pm \mathbf{S D}$ & $\begin{array}{c}\text { Test and } \\
\text { significance }\end{array}$ \\
\hline \multirow{3}{*}{ Age (years) } & $17-19$ years & 166 & $128.75 \pm 15.86$ & F: 0.605 \\
\hline & 20-22 years & 252 & $130.40 \pm 17.22$ & $\mathrm{p}: 0.546$ \\
\hline & 23 and above & 36 & $128.44 \pm 13.72$ & \\
\hline \multirow[t]{2}{*}{ Gender } & Female & 317 & $130.62 \pm 16.08$ & $\mathrm{t}: 1.917$ \\
\hline & Male & 137 & $127.40 \pm 17.18$ & p: 0.056 \\
\hline \multirow[t]{2}{*}{ Marital Status } & Single & 444 & $129.66 \pm 16.57$ & $\mathrm{t}: 0.107$ \\
\hline & Married & 10 & $129.10 \pm 11.87$ & $\mathrm{p}: 0.915$ \\
\hline \multirow[t]{4}{*}{ School Year } & 1st class & 133 & $128.21 \pm 18.07$ & \\
\hline & 2nd class & 141 & $131.29 \pm 16.31$ & $F: 1.517$ \\
\hline & 3rd class & 92 & $131.15 \pm 14.13$ & P:0.209 \\
\hline & 4th class & 88 & $127.61 \pm 16.30$ & \\
\hline \multirow{4}{*}{$\begin{array}{l}\text { Frequency of seeing the } \\
\text { elderly people in your } \\
\text { family }\end{array}$} & Every day & 70 & $132.41 \pm 17.04$ & \\
\hline & $\begin{array}{l}\text { Few times a } \\
\text { week }\end{array}$ & 106 & $131.31 \pm 13.96$ & $F: 2.171$ \\
\hline & $\begin{array}{l}\text { Few times a } \\
\text { month }\end{array}$ & 148 & $127.32 \pm 15.67$ & P:0.091 \\
\hline & $\begin{array}{l}\text { Few times a } \\
\text { year }\end{array}$ & 104 & $129.48 \pm 16.93$ & \\
\hline \multirow{7}{*}{$\begin{array}{l}\text { Reading books regarding } \\
\text { old age } \\
\text { Following news regarding } \\
\text { elderly people } \\
\text { Being willing to work in } \\
\text { an institution providing } \\
\text { care to the elderly }\end{array}$} & Yes & 35 & $130.65 \pm 15.31$ & $\mathrm{t}: 0.376$ \\
\hline & No & 419 & $129.56 \pm 16.58$ & p:0.707 \\
\hline & Yes & 207 & $132.90 \pm 15.72$ & $\mathrm{t}: 3.919$ \\
\hline & No & 247 & $126.91 \pm 16.62$ & $\mathrm{P}<0.001$ \\
\hline & Yes & 159 & $134.34 \pm 16.03$ & $F: 17.259$ \\
\hline & No & 65 & $120.78 \pm 18.95$ & $\mathrm{P}<0.001$ \\
\hline & Undecided & 230 & $128.90 \pm 14.86$ & \\
\hline
\end{tabular}

\section{DISCUSSION}

Healthcare services have been increasingly used by old people because of an increase in longevity, frequency of disorders, and ease of access to healthcare services; therefore, healthcare professionals are increasingly exposed to the elderly people (Şahin \& Erdem, 2017). Negative attitudes of healthcare professionals, especially nurses who provide care for the elderly population, toward old people affect the quality of the care provided to this population (Rathnayake et al., 2016). Nursing training has a significant role in developing 
positive attitudes toward the elderly people. This study found that nursing students had a positive attitude toward the elderly population. These findings may be attributed to the values and common laws of our society in addition to the fact that respecting elderly people remains a significant tradition in the Turkish society despite the socioeconomic and cultural changes. In addition, previous studies showed that student nurses had a positive attitude toward elderly people (Che et al., 2018; Şahin \& Erdem, 2017; Rathnayake et al., 2016; Sar1 et al., 2019; Alkaya \& Okuyan, 2017; Hsu et al., 2019; Ghimire at al., 2019; Söylemez et al., 2018).

Nurses play an important role in providing care for the elderly population (Rathnayake et al., 2016). In this study, no change was observed in the scores of attitude toward older people based on the age of the students. Our findings were consistent with those of some previous studies (Adibelli et al., 2013), whereas other studies reported that students developed positive attitudes as they became older (Ayoğlu et al., 2014; Wanko Keutchafo \& Kerr, 2020).

Given the ever-aging population of Turkey, in the future, well-educated and talented nurses who devote themselves to work with elderly people in various environments to provide holistic care for them will be required (Hsu et al., 2019). Results of this study showed a similar distribution of scores of the attitudes of female and male students toward elderly people. The attitudes of nursing students in this study toward older people were observed regardless of their gender, which was a positive finding and was consistent with that reported previously (Adibelli, Türkoğlu \& Kılıç, 2013; Sar1 et al., 2019; Wanko Keutchafo \& Kerr, 2020). Some previous studies showed that female students had more positive attitudes toward older people (Hsu et al., 2019; Türgay et al., 2015; Lambrinou et al., 2009), whereas others showed that male students had more positive attitudes toward older people (Şahin \& Erdem, 2017; Ayoğlu et al. 2014).

Institutions providing nursing education play a significant role in changing the attitude and work preferences of the nursing students toward older people. In this study, it was expected that the scores of final year students would be higher. But, the attitudes of nursing students toward older people remained same irrespective of their study years in the university. Previous studies indicated that positive attitudes toward older people increased with higher education (Lambrinou et al., 2009; Bleijenberg, 2012), whereas findings of other studies were consistent with those observed in this study (Şahin \& Erdem, 2017; Rathnayake et al., 2016; Ayoğlu et al. 2014; Wanko Keutchafo \& Kerr, 2020). Differences within the study results may be related to the differences in the the family and the scores of the attitudes of students toward older people. A previous 


\section{Evrim ÇELEBİ \& Fatoş UNCU}

study showed that nursing students living with an older individual, providing care to elderly family members, and communicating with elderly people daily had higher mean scores of attitudes toward older people (Alkaya \& Okuyan, 2017).

An increasing elderly population has led to an increase in the problems related to old age and chronic disorders, which in turn has increased the burden of providing care for the elderly. Thus, it is important for nursing students to learn about old age and providing care for the elderly population (Alkaya \& Okuyan, 2017). Results of this study showed that students who read news regarding elderly people had significantly higher scores than those who did not following such news. Results of a previous study conducted in Turkey showed no differences in the scores of attitudes toward old age of the participants based on whether or not they followed news regarding old age in the media (Koç, 2017).

\section{CONCLUSION}

Results of this study showed that nursing students generally had a positive attitude toward the elderly irrespective of their age, gender, and their year. The significance of care for the elderly is gradually increasing among the different tasks performed by the nurses. Therefore, nurses need to be adequately prepared to fulfill the healthcare needs of the elderly population. This study emphasizes the importance of strengthening the geriatric and gerontology components in the undergraduate curricula of nursing students and providing them the opportunity to work with elderly people for improving their attitudes toward old age. Institutions educating nurses should make an effort to develop educational interventions for increasing and encouraging their intention to work with the elderly.

\section{Limitations}

This study only evaluated the attitudes of nursing students in a single university toward the elderly population. Therefore, these results cannot be generalized to all nursing students in Turkey. More studies with a larger sample size are recommended. 
Nursing Students' Attitudes towards the Elderly and Affecting Factors

\section{REFERENCES}

Adıbelli, D., Türkoğlu, N., \& Kılıç, D. (2013). Determining Critical thinking dispositions of nursing: A comperative study. Dokuz Eylül Üniversitesi Hemşirelik Yüksekokulu Elektronik Dergisi, 6(1), 2-8.

Alkaya, S., \& Okuyan, C. (2017). Nursing students' attitudes towards the elderly. Journal of Hacettepe University Faculty of Nursing, 4(1), 43-52.

Ayoğlu, F.N., Kulakçı, H., Ayyıldız, T.K., Aslan, G.K., \& Veren, F. (2014). Attitudes of Turkish nursing and medical students toward elderly people. Journalof Transcultural Nursing, 25(3), 241-248. https://doi.org/10.1177/ 1043659613515527

Beard, J.R., Officer, A., De Carvalho, I.A., Sadana, R., Pot, A.M., Michel, J.P., et al. (2016). The world report on ageing and health: A policy framework for healthy ageing. The Lancet, 387 (10033), 2145-2154. https://doi.org/10.1016/S0140-6736(15)00516-4

Birimoglu, O.C., Bilgili. N., \& Mutlu, A. (2020). Factors affecting nursing students' intention to work as a geriatric nurse with older adults in Turkey: A cross-sectional study. Nurse Educ Today, 95(June), 104563. https://doi.org/10.1016/j.nedt.2020.104563

Bleijenberg, N. (2012). Dutch nursing students' knowledge and attitudes towards older people - A longitudinal cohort study. J Nurs Educ Pract. 2(2), 1-8.

Che, C.C., Chong, M.C., \& Hairi, N.N. (2018). What influences student nurses' intention to work with older people? A cross-sectional study. International Journal of Nursing Studies, 85, 61-67. https://doi.org/10.1016/ j.ijnurstu.2018.05.007

Deltsidou, A., Gesouli-Voltyraki, E., Mastrogiannis, D., Mantzorou, M., \& Noula, M. (2010). Nurse teachers' and student nurses' attitudes towards caring the older people in a province of Greece. Health Sci Journal, 4(4), 245-257.

Demirtaş, Z., Sağlan, R., Arslantaş, D., \& Ünsal, A. (2019). Nurses' Attitudes towards older People at a University Hospital. Journal of Geriatric Science, 2(2), 36-41.

Duru Aşiret, G., Türten Kaymaz, T., Canpolat, Ö., \& Kapucu, S. (2015). Attitudes of nurses towards older people. Hemşirelikte Araştırma Geliştirme Dergisi, 17, 10-20. 
Duyan, V., \& Gelbal, S. (2013). The adaptation of attitudes towards the elderly scale to Turkish with a group of university students. Türk Geriatri Dergisi, 16(2), 202-9.

Erden, İ.A., Kara, D., Ayhan, B., \& Uzun, Ş. (2012). Geriatrik hasta ve yoğun bakım. Akademik Geriatri, 4, 115-119.

Ghimire, S., Shrestha, N., Callahan, K.E., Nath, D., Baral, B.K., Lekhak, N., et al. (2019). Undergraduate nursing students' knowledge of aging, attitudes toward and perceptions of working with older adults in Kathmandu Nepal. Int J Nurs Sci, 6(2), 204-210. https://doi.org/10.1016/j.ijnss.2019.03.003

Hsu, M.H.K., Ling, M.H., \& Lui, T.L. (2019). Relationship between gerontological nursing education and attitude toward older people. Nurse Educ Today, 74, 85-90. https://doi.org/10.1016/j.nedt.2018.12.007

Koç, N.A. (2017). Identification of the Attitudes of the Social Service Professionals towards the Elderly and the Geriatric Social Work Competencies: Ankara Sample. Master's thesis, Ankara University Health Sciences Institute.

Kogan, N. (1961). Attitudes toward old people: The development of a scale and an examination of correlates. J Abnormal Psychol, 62(1), 44-54.

Lambrinou, E., Sourtzi, P., Kalokerinou, A., \& Lemonidou, C. (2009). Attitudes and knowledge of the Greek nursing students towards older people. Nurse Education Today, 29(6), 617-622. https://doi.org/10.1016/j.nedt.2009. 01.011

Özdemir, Ö., \& Bilgili, N. (2014). Ageism in health care. Gülhane Tip Dergisi, 56, 128-131. https://doi.org/10.5455/gulhane. 32088

Özütürker, S. (2019). Erzincan Binali Yıldırım University social work students' views of elderly. Elderly Issues Research Journal, 12 (2), 107-112.

Rathnayake, S., Athukorala, Y., \& Siop, S. (2016). Attitudes toward and willingness to work with older people among undergraduate nursing students in a public university in Sri Lanka: A cross sectional study. Nurse Education Today, 36, 439-44. https://doi.org/10.1016/j.nedt.2015.10.007

Sarı, D., Baysal, E., Taşkıran, N., Acar, E., \& Akyıl, R.Ç. (2019). Attitudes of nursing students towards elderly people and empathic approach skills. SDÜ Sağllk Bilimleri Enstitüsü Dergisi, 10(2), 80-87. https://doi.org/10.22312/sdusbed.490498 
Nursing Students' Attitudes towards the Elderly and Affecting Factors

Shen, J., \& Xiao, L.D. (2012). Factors affecting nursing students' intention to work with older people in China. Nurse Education Today, 32(3), 219-23. https://doi.org/10.1016/j.nedt.2011.03.016

Söylemez, B.A., Küçükgüçlü, Ö., Tekin, D., Ergin, S.B., \& Yaman, A.(2018). Examining nursing students' attitudes towards the elderly and factors affecting attitudes towards the elderly. Dokuz Eylül Üniversitesi Hemşirelik Fakültesi Elektronik Dergisi, 11(2), 173-179.

Şahin, H., \& Erdem, Y. (2017). Determining the attitudes of nursing students toward the elderly. Türkiye Sosyal Araştırmalar Dergisi, 21(1), 175-187.

TÜİK (2019). Istatistiklerle yaşlılar. https://data.tuik.gov.tr/Bulten/Index?p= Istatistiklerle-Yaslilar-2019-33712, Access date: 27.12.2020.

Turgay, A.S., Şahin, S., Aykar, F.Ş, Sari, D., Badir, A., \& Özer, Z.C. (2015). Attitudes of Turkish nursing students toward elderly people. Eur Geriatr Med. 6(3), 267-270. https://doi.org/10.1016/j.eurger.2015.01.006

United Nations. (2020). World Population Ageing 2020 Highlight. https://www.un.org/development/desa/pd/sites/www.un.org.development. desa.pd/files/undesa_pd-2020_world_population_ageing_highlights.pdf Access date: 27.12.2020

Wanko Keutchafo, E.L., \& Kerr, J. (2020). Cameroonian nursing students' attitudes towards older adults. Int $J$ Africa Nurs Sci, 13:100215. https://doi.org/10.1016/j.ijans.2020.100215

Y1lmaz, E., \& Özkan, S. (2010). Attitudes of Nursing Students towards Ageism. Maltepe Üniversitesi Hemşirelik Bilim ve Sanatı Dergisi, 3(2), 35-52.

\section{EXTENDED ABSTRACT}

Aim: The number of people aged 65 and older was 727 million in 2020. The global elderly population is expected to more than double by 2050 and is expected to be $>1.5$ billion. The elderly population is expected to increase worldwide between 2020 and 2050; the population comprising individuals aged 65 and older is expected to increase from $9.3 \%$ in 2020 to $16.0 \%$ in 2050. In Turkey, adults aged 65 and older comprised the $9.1 \%$ of the total population in 2019. According to population projections, the proportion of elderly population is expected to increase to $10.2 \%$ in $2023,12.9 \%$ in 2030 , and $16.3 \%$ in 2040 . Healthcare institutions and healthcare professionals usually define elderly people as the ones who occupy beds, require hospitalization, and who cannot be treated within the 
healthcare system; therefore they are evaluated as a failure within the healthcare system. The perceptions, perspectives, and prejudices of nurses regarding old age directly or indirectly affect the studies regarding the health of elderly people. Moreover, owing to the changes associated with aging, it becomes difficult for the nurses to provide care to the elderly people, and the increase in workload affects their desire to work with this population. The nursing students today will be the nurses to directly provide care to the aging population tomorrow. Therefore, determining the knowledge and attitudes of the nursing students regarding the elderly population has become extremely significant. This study was conducted to determine the attitudes of nurses regarding elderly people and the factors affecting their attitudes.

Materals and methods: This was a cross-sectional and descriptive study. The study population included 454 students studying in the nursing department of the faculty of health sciences in the Firat University during the spring semester from 2018-2019. Study data were collected using a personal information form and Kogan's Attitudes toward Old People Scale (KATOPS). Variables were summarized as number, percentage, and average. Data were analyzed using a ttest in the independent groups and analysis of variance (ANOVA). All data were analyzed using the IBM SPSS Statistics version 25.0 statistical software program and the significance level was statistically set at $\mathrm{p}<0.05$.

Results: The mean scores on the positive and negative attitude subscales were $65.63 \pm 10.45$ and $64.01 \pm 12.05$, respectively, and the mean total score was $129.64 \pm 16.47$. Mean scale scores of the students following the news regarding the elderly population $(132.90 \pm 15.72)$ were significantly higher than those not following such news $(126.91 \pm 16.62, \mathrm{p}<0.001)$. Students willing to work at an institution providing service to elderly people after graduation had statistically higher scores than those who were unwilling and indecisive about working at such an institution $(\mathrm{p}<0.001)$. The mean scores of students based on variables of age, gender, marital status, year, frequency of meeting the elderly relatives within the family, and reading books about old age showed a similar distribution.

Conclusion and discussion: Results of this study showed that nursing students generally had a positive attitude toward the elderly irrespective of their age, gender, and their year. The significance of care for the elderly is gradually increasing among the different tasks performed by the nurses. Therefore, nurses need to be adequately prepared to fulfill the healthcare needs of the elderly population. Institutions educating nurses should make an effort to develop educational interventions for increasing and encouraging their intention to work with the elderly. 